\title{
The effect of 12 weeks endurance training at 2 different intensities on GLUT4 mRNA expression of soleus and gastrocnemius muscles in obese mice
}

\author{
Hamid Mohebbi ${ }^{a, *}$, Hadi Rohani ${ }^{b}$, Sadegh Hassan-Nia ${ }^{c}$ \\ a Department of Exercise Physiology, Faculty of Physical Education and Sport Sciences, University of Guilan, Rasht, Iran \\ ${ }^{b}$ Department of Sport Medicine, Sport Sciences Research Institute of Iran, Tehran, Iran \\ c Faculty of Biological Science, Tarbiat Modares University, Tehran, Iran
}

Received 10 October 2015; accepted 14 December 2015

Available online 10 March 2016

\section{KEYWORDS \\ Endurance training; \\ Muscle type; \\ Obesity; \\ GLUT4}

\begin{abstract}
The aim of this study was to investigate the expression of GLUT4 mRNA in soleus and gastrocnemius muscles in obese mice in response to endurance training. Forty male C57BL/ 6 mice were used in this study. Eight mice (Normal Base [NB]) served as non-obese non-trained controls, and 32 mice were put on a high fat diet (HFD) regimen $(60 \% \mathrm{kcal}$ fat) for 12 weeks. At week 16, the obese mice were randomized into the following treatment groups $(n=8$ each group): Obese Base [OB]; Low Intensity [LI]; High Intensity [HI]; or Obese Control [OC] groups. LI and $\mathrm{HI}$ trained for 5 days/week for 12 weeks on a motorized treadmill at $15 \mathrm{~m} / \mathrm{min}$ on a $5 \%$ slope (for $\mathrm{LI}$ ), and/or at $22 \mathrm{~m} / \mathrm{min}$ on a $5 \%$ slope (for $\mathrm{HI}$ ). OC mice were kept sedentarily in the cage during the training program. GLUT4 mRNA expression was measured in gastrocnemius and soleus muscles using a Real Time-PCR method. GLUT4 mRNA expression of soleus muscle in LI group increased about 2.2 fold, against about 1.6 fold for gastrocnemius $(p<.05)$. In addition, GLUT4 mRNA expression of soleus and gastrocnemius muscles in $\mathrm{LI}$ and $\mathrm{HI}$ groups were significantly higher than $\mathrm{OB}$ and $\mathrm{OC}$ groups $(p<.05)$. It can be concluded that any disturbance in body energy balance, especially by exercise training and/or high fat diet can influence these molecular and cellular mechanisms that act to establish a stable homeostasis.

(c) 2015 Consell Català de l'Esport. Generalitat de Catalunya. Published by Elsevier España, S.L.U. All rights reserved.
\end{abstract}

\footnotetext{
* Corresponding author.

E-mail addresses: Mohebbi_h@yahoo.com, mohebbi@guilan.ac.ir (H. Mohebbi).
} 


\section{PALABRAS CLAVE}

Entrenamiento de Resistencia; Tipo muscular; Obesidad;

GLUT4

\section{Introduction}

It is generally accepted that obesity is predominantly associated with an impaired insulin-stimulated glucose uptake rate in skeletal muscle, which has been attributed to insulin resistance. Many studies have focused on the glucose transporter system as part of the underlying mechanisms. Glucose transport into the skeletal muscle cell mediated by the glucose transporter proteins GLUT1 and GLUT4. ${ }^{1}$ The GLUT1 glucose transporter isoform is thought to support basal glucose transport, ${ }^{2,3}$ while the GLUT4 isoform increases glucose transport in response to insulin and contraction. Insulin and contractions translocate the GLUT4 from the intracellular pool to the plasma membrane and to the T-tubules. ${ }^{4,5}$

In rodents, it is well known that the glucose uptake capacity is greater in red oxidative muscles than in white glycolytic muscles. ${ }^{6-10}$ One underlying mechanism seems to be a greater level of GLUT4 expression, both intracellularly ${ }^{6,7}$ and at the plasma membrane. ${ }^{8}$ In human skeletal muscle, glucose uptake was positively associated with the proportion of type I fibers and negatively associated with the proportion of type Ilb fibers. ${ }^{11}$ These results were supported in the in vitro study by Zierath et al. ${ }^{12}$ that reported the insulinstimulated increase in glucose uptake over basal is strongly correlated, both positively with the percentage of type I muscle fibers and negatively with the percentage of type Ila fibers. However, unconvincing results regarding the relationship between fiber type distribution and GLUT4 content in human muscle have been reported. ${ }^{13-15}$ Andersen et al. ${ }^{13}$ found no correlation between fiber type and GLUT4 content, whereas Houmard and colleagues ${ }^{15}$ showed a weak correlation between fiber type composition and GLUT4 content.
It has been shown that different muscles exhibit large differences in their GLUT4 content, and this variation is often associated with differences in insulin-stimulated glucose uptake. ${ }^{16,17}$ As different muscles are composed of a mixture of several different muscle fiber types, ${ }^{18}$ it is possible that a significant difference exists in GLUT4 content between muscles.

Possibly, the differences in GLUT4 content and insulinstimulated glucose uptake are more related to training status. Changes in the skeletal muscle activity level is a key regulator of GLUT4 content in rats. ${ }^{19,20}$ In humans, athletes have more GLUT4 than untrained age-matched control subjects, ${ }^{21,22}$ and in both normal healthy control subjects and individuals with diminished insulin-stimulated glucose uptake, exercise training has been shown to increase GLUT4 content. ${ }^{20,23,24}$ Additionally, a decrease in activity level will decrease GLUT4 content. ${ }^{20,25}$ Finally, changes in physical activity and GLUT4 content have been shown to be connected with changes in insulin-stimulated glucose uptake. ${ }^{20}$

The main objective of our work was to investigate the GLUT4 mRNA expression in soleus (a predominantly slow-twitch muscle) and gastrocnemius (a predominantly fast-twitch muscle) in obese mice in response to endurance training.

\section{Subjects and methods}

\section{Animals}

Forty male C57BL/6 mice (4 weeks age) were used in this study. Eight non-obese mice (Normal Base [NB] group; 
Standard diet fed ad libitum) served as non-obese nontrained controls (NB group was considered as a baseline value in calculating gene expression in Real-Time that is expressed as relative values) and 32 mice were put on a high fat diet (HFD) regimen for $12 \mathrm{wk}$ consisting of ad libitum access to a 60\% kcal fat diet (High-Fat Diet, Razi Vaccine \& Serum Research Institute, Iran). At week 16, the obese mice were randomized into the following treatment groups ( $n=8$ each group): (1) Obese Base [OB] group; (2) Low Intensity [LI] group; (3) High Intensity [HI] group; or (4) Obese Control $[\mathrm{OC}]$ group. $\mathrm{OB}$ mice were killed before the training program. LI and $\mathrm{HI}$ trained for 5 days/wk for $12 \mathrm{wk}$ on a motorized treadmill. OC served as non-trained controls. All mice were housed binary in cages and the temperature of the animal room was maintained at $22^{\circ} \mathrm{C}$, and an artificial 12:12-h light-dark cycle was set. A familiarization period of two weeks in which mice ran $7-10 \mathrm{~m} / \mathrm{min}$ for $10-15 \mathrm{~min}$ on a $5 \%$ slope was applied. Thereafter, training was continued in next $12 \mathrm{wk}$ for $60 \mathrm{~min}$ continuously at $15 \mathrm{~m} / \mathrm{min}$ on a $5 \%$ slope (for LI) and/or for 41 min continuously at $22 \mathrm{~m} / \mathrm{min}$ on a $5 \%$ slope (for $\mathrm{HI}$ ). Total daily work was matched for both groups and set at $900 \mathrm{~m}$ distance running. OC mice were kept sedentarily in the cage during the training program. Weight was recorded weekly. $\mathrm{LI}, \mathrm{HI}$ and $\mathrm{OC}$ were killed at end of training program. Food was withdrawn $12-14 \mathrm{~h}$ before killing. Experiments were approved by the Research Ethics Committee.

\section{Muscle preparation}

Mice were anesthetized intraperitoneally with a mixture of Ketamine (30-50 mg/kg bw) and Xylazine (3-5 mg/kg bw) and were killed via direct heart blood withdrawal for muscle sampling $48 \mathrm{~h}$ after last exercise session, and the soleus and gastrocnemius muscles were dissected. Muscle samples were quickly frozen into liquid nitrogen and stored at $-80^{\circ} \mathrm{C}$. Tissue preparation and total RNA extraction procedures are described elsewhere in details. ${ }^{26}$

\section{Real-time PCR}

RNA was reverse-transcribed with reverse transcriptase and random hexamer primers according to the manufacturer's instructions (AccuPower Green Star qPCR PreMix, BiONEER, Daejeon, Korea). Then, PCR-mastermix containing the specific primers, Hot Star Taq DNA polymerase and SYBR-Green PCR buffer were added. All the samples were determined as duplicates, and for a negative control the same set-up was used except for the addition of reverse transcriptase. No PCR product was detected under these latter conditions.

GLUT4 mRNA and $\beta$-actin, a house-keeping gene, levels were determined by quantitative reverse transcription-PCR of total cell RNA by using the forward primer $5^{\prime}$ CCG CGG CCT CCT ATG AGA TAC T3' and the reverse primer 5' AGG CAC CCC GAA GAT GAG T3' for amplification of GLUT4 mRNA and the forward primer $5^{\prime}$ ACA ATG AGC TGC GTG TGG CC $3^{\prime}$ and the reverse primer 5' CCT CGT AGA TGG GCA CAG TG $3^{\prime}$ for amplification of $\beta$-actin mRNA. Amplification products were electrophoresed on $2 \%$ agarose gels and stained with ethidium bromide.
Real-time quantitation of GLUT4 to $\beta$-actin mRNA was performed using a SYBR-Green PCR assay (Rotor-gene 6000, Corbett). GLUT4 mRNA and $\beta$-actin mRNA were amplified in separate tubes and the thermal cycling protocol for 40 cycles was denaturation at $95^{\circ} \mathrm{C}$ for $20 \mathrm{~s}$, annealing at $60^{\circ} \mathrm{C}$ for $60 \mathrm{~s}$, extension at $72{ }^{\circ} \mathrm{C}$ for $30 \mathrm{~s}$ that started with initial denaturation at $95^{\circ} \mathrm{C}$ for $15 \mathrm{~min}$ and completed with final extension at $72{ }^{\circ} \mathrm{C}$ for $10 \mathrm{~min}$. During the extension step, increase in fluorescence was measured in real time. Data were obtained as CT values (threshold cycle). Relative gene expression was calculated using the Pfaffl formula ${ }^{27}$ :

$$
\text { Ratio }=\frac{\left(E_{\text {target }}\right)^{\Delta C T_{\text {target }}^{(\text {(control-sample })}}}{\left(E_{\text {ref }}\right)^{\Delta C T_{\text {ref }}^{(\text {control-sample })}}}
$$

\section{Data analysis}

Values are presented as mean $\pm \mathrm{SD}$. One-way analysis of variance (ANOVA) followed by Tukey's Honestly Significant Differences test were used to assess the effects of training on relative mRNA expression of GLUT4 in different groups. Paired $t$-test, also, was used to assess the differences between soleus and gastrocnemius muscle GLUT4 mRNA in each group. For all tests SPSS 21.0 software was used (SPSS Inc., Chicago, IL, USA), and $p \leq 0.05$ was considered statistically significant.

\section{Results}

Mean weight values of mice in different groups during HFD feeding and training phases are presented in Fig. 1. Weight in those groups who consumed HFD (i.e. OB, OC, $\mathrm{LI}$ and $\mathrm{HI}$ ) have significantly increased compared to NB from the 5th week during HFD feeding phase which stayed higher until the 12 th week $(p \leq 0.05)$. The weight gain in all 4 treatment groups was $18 \%$ in average compared to NB that reached $32 \%$ at the 12th week (Fig. 1).

During the training phase, only the training groups (LI \& $\mathrm{HI}$ ) and $\mathrm{OC}$ were studied and weight loss in training groups started to differentiate from OC group from the 6th week which became significant from the 8th week $(p \leq 0.05)$. So that, weight loss in training groups (compared to OC group) was $5 \%$ and $7 \%$ in the 6 th and 12 th weeks of training phase, respectively. Interestingly, the difference of weight loss between $\mathrm{LI}$ and $\mathrm{HI}$ appeared from the 9th week and became statistically different in the 11th and 12th weeks $(p \leq 0.05)$. In fact, the rate of weight loss was higher in $\mathrm{HI}$ than LI, so that weight changes percentage at the end of 12 weeks training in $\mathrm{HI}$ group was $8 \%$ vs. $5.5 \%$ in $\mathrm{LI}$ group.

GLUT4 mRNA expression of soleus muscle in the mice who engaged in $\mathrm{LI}$ group increased about 2.2 fold, against $\sim 1.6$ fold for gastrocnemius, relative to NB $(p \leq 0.05)$; similarly, relative GLUT4 mRNA expression increased, albeit statistically nonsignificant, by high intensity exercise training in soleus and gastrocnemius muscles by $\sim 2.1$ and $\sim 1.8$ fold, respectively $(p>0.05)$. In addition, GLUT4 mRNA expression of soleus and gastrocnemius muscles in $\mathrm{LI}$ and $\mathrm{HI}$ groups were significantly higher than $\mathrm{OB}$ and $\mathrm{OC}$ groups $(p \leq 0.05)$, which have slightly down-regulated in latter groups (Fig. 2). 


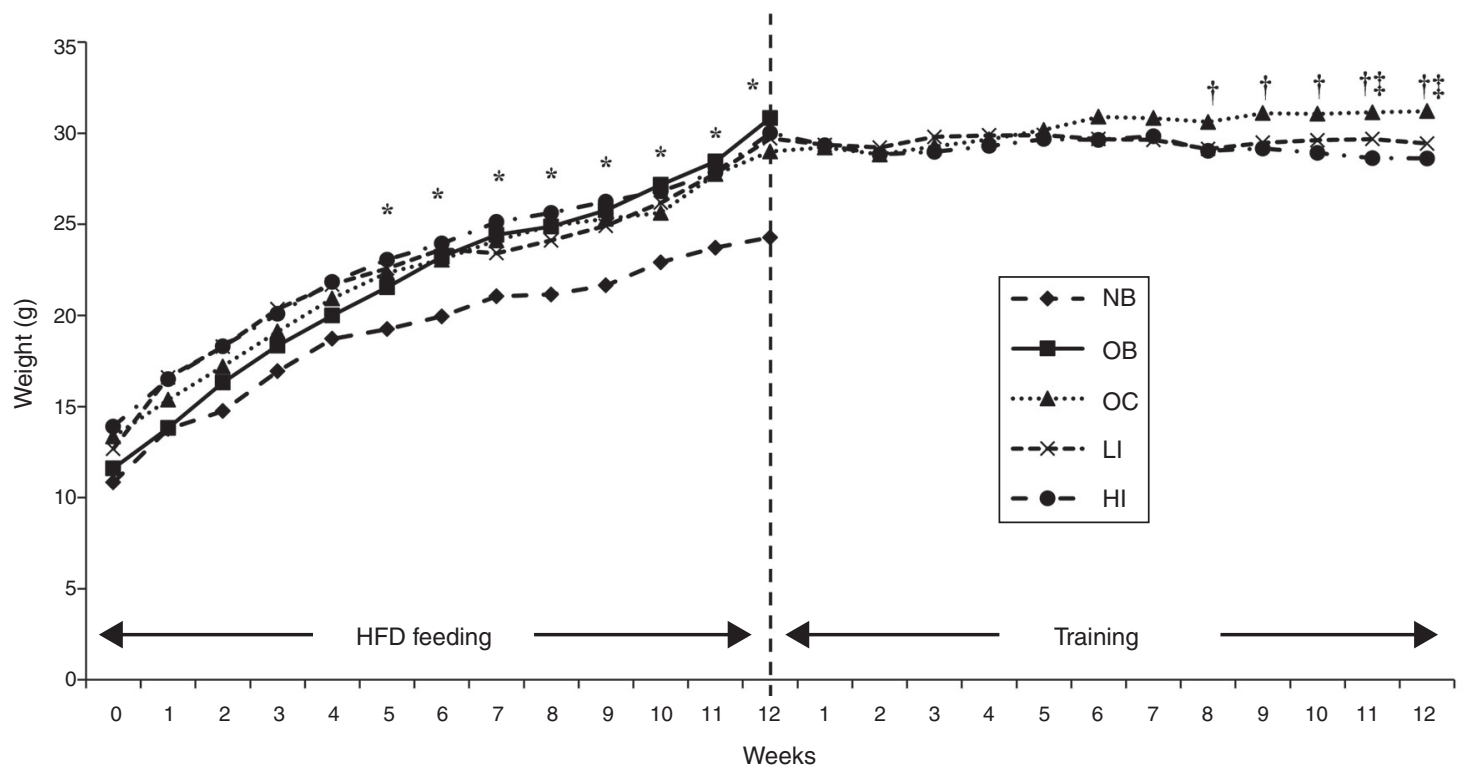

Figure 1 Weight changes in mice during HFD feeding and training phases. *, significant difference between obese and NB groups; $\dagger$, significant difference between training groups and $\mathrm{OB} ; \ddagger$, significant difference between $\mathrm{HI}$ and $\mathrm{LI}$ groups. NB=Normal Base, $\mathrm{OB}=$ Obese Base, $\mathrm{OC}=$ Obese Control, $\mathrm{LI}=$ Low Intensity training, $\mathrm{HI}=$ High Intensity training.

\section{Discussion}

Ploug et al. ${ }^{28}$ found that GLUT4 in nonstimulated (by insulin) fibers is distributed along all the muscle fibers, and is present both at the surface (68\% of total GLUT4) and in the core (32\% of total GLUT4) of the fibers. They also found that the nuclei are displaced by and aligned with the blood vessels that course along the fiber surface, thereby placing a large fraction of GLUT4 close to the source of glucose and obviating the need for diffusion over long distances. ${ }^{28}$ It is well documented that in the normal state, GLUT4 cycles slowly between the plasma membrane and one or more intracellular compartments, with the vast majority of the transporter residing in vesicular compartments within the cell interior. ${ }^{28,29}$ Insulin stimulated accumulation of GLUT4 protein at the cell surface can be caused by 10-20

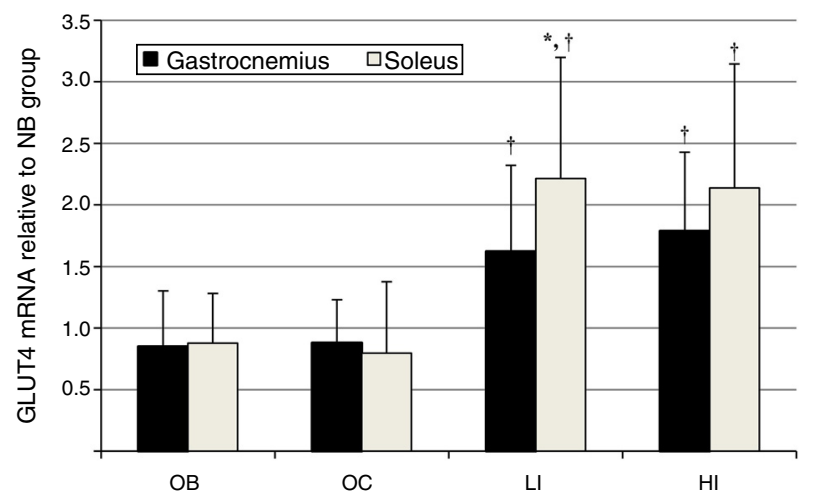

Figure 2 GLUT4 mRNA content of experimental groups' gastrocnemius and soleus muscle relative to matched muscle in NB group. *, significant increase relative to NB $(p \leq 0.05)$; $\dagger$, significant difference in compare to $\mathrm{OB}$ and $\mathrm{OC}(p \leq 0.05)$. fold increase in the rate of exocytosis with a smaller decrease $(2-3$ fold $)$ in the rate of GLUT4 endocytosis. ${ }^{5,10,30}$

Insulin stimulates glucose transport through GLUT4 translocation from the intracellular storage pool to the plasma membrane. Insulin resistance caused by insulin deficiency or abnormal insulin signaling results in a decrease in GLUT4 expression and translocation, and then causes hyperglycemia and diabetes. ${ }^{30-32}$ Muscle contraction has also been shown to increase GLUT4 content in the cell membrane. ${ }^{29,30}$ Many studies suggest that exercise training cause GLUT4 protein expression and translocation to plasma membrane by a distinct mechanism from insulin signaling. ${ }^{5,33}$ Most studies on rat skeletal muscle have indicated that more GLUT4 is present in the type I fibers compared with the type II fibers, ${ }^{10,34}$ as we found in mice, too. In this study, we used only the soleus muscle, generally known as a type I muscle.

Our study is in agreement with other studies ${ }^{35-39}$ that indicate exercise trainings increase GLUT4 protein expression in diabetic subjects like as what occurred in our obese subjects.

We found that GLUT-4 mRNA expression is increased by 12 weeks endurance training, both in soleus (a predominantly slow-twitch muscle) and gastrocnemius (a predominantly fast-twitch muscle) in obese mice, with an intensity-depended pattern. This means that exercise intensity can affect the GLUT-4 gene expression (and, probably, protein) response to training which may result in significant metabolic changes especially in obese cases. In agreement with our findings, it has been shown that, GLUT-4 protein and glucose transport are markedly higher in red-oxidative (type $\mathrm{I}$ and $\mathrm{Ila}$ ) muscle fibers than in white-glycolytic fibers (type $\mathrm{Ilb}){ }^{10,40}$ This might be an important factor in the adaptation to exercise, because endurance training results in a shift from type Ilb to type lla fibers. ${ }^{41}$ However, in human skeletal muscles, there is a much smaller difference in the GLUT-4 expression in different muscle fiber types. ${ }^{34,42}$ 
Daugaard et al. ${ }^{34}$ isolated individual muscle fibers and typed them according to myosin isoform. GLUT-4 was 20\% higher in fibers expressing myosin heavy chain I than in those expressing myosin heavy chain IIA or IIB. No difference could be detected between Ila and Ilb fibers. After 2 weeks of exercise training, GLUT- 4 was increased by $\sim 23 \%$ in type I muscles, but there were no changes in type lla or Ilb. However, the low-intensity exercise that was used is primarily known to recruit type I fibers.

According to our findings, low intensity exercise training resulted in increased expression of GLUT4 mRNA in the oxidative muscle (i.e. soleus), probably due to cell requirements related to cellular oxidative capacity. On the other hand, high intensity exercise training did not result in increased expression of GLUT4 mRNA in the soleus, nor in the gastrocnemius muscles. As gastrocnemius muscle consists the mixture of red and white fibers, another explanation would be that exercise training with low intensity was not enough to exercise or even activate red fibers of the gastrocnemius muscle, and a nonsignificant increase in this muscle may be come from its white fibers. This scenario can be extended to what observed findings related to high intensity; i.e. a nonsignificant increase in this muscle by high intensity exercise may be come from its red fibers only.

Hormones also regulate muscle glucose transporter protein concentration. GLUT-4 expression was increased by insulin and thyroid hormones ${ }^{20,43}$ and decreased by elevated cAMP. ${ }^{44}$ Regulation of GLUT- 4 expression by contractile activity is independent of hormonal regulation, because treadmill running increased GLUT-4 in diabetic rats. ${ }^{45}$ The effects of insulin-deficiency and denervation on GLUT-4 concentrations were additive. ${ }^{45}$ Physical training also increases muscle GLUT-4 protein and mRNA in patients with type 2 diabetes. ${ }^{46}$ These results suggest that muscle contractile activity directly modulates muscle GLUT-4 expression, independent of insulin action. Histone deacetylase (HDAC5) is a critical mediator of changes to GLUT4 mRNA levels in response to exercise. ${ }^{51} \mathrm{~A}$ series of histone modifications mediated by histone deacetylases and histone methyltransferases have been shown to climax in a metabolic knockdown of the GLUT4 gene in the skeletal muscle of rats. ${ }^{52}$

There is considerable evidence that GLUT4 mRNA levels in adipose and muscle tissue decrease with obesity, ${ }^{47,48}$ and that increases in GLUT4 mRNA can alleviate or compensate insulin resistance. ${ }^{49,50}$ Indeed, our finding that GLUT4 mRNA levels were significantly increased by exercise training, and this increase was associated with weight loss, supports this idea. Therefore, increased transcription of GLUT4 in muscle during weight loss may be a certain event in reversing insulin resistance.

Collectively, previous studies and our findings suggest that transcriptional regulation of the GLUT4 gene is responsive to body energy balance changes. Additionally, we found an intensity- and fiber type-dependent response of GLUT4 to exercise training that is not considered in previous studies.

It can be concluded that any disturbance in body energy balance especially by exercise training and/or high fat diet can influence such molecular and cellular mechanisms which act to establish a stable homeostasis. GLUT4 would decrease if energy intake is increased and, reversely, would increase if energy expenditure is increased. These changes are almost similar in slow- and fast-twitch muscles with slightly more responsiveness in slow-twitch muscles that are more engaged in glucose metabolism.

\section{Conflicts of interest}

The authors have no conflicts of interest to declare.

\section{Acknowledgment}

Authors would like to thank University of Guilan which financially supported this research project.

\section{References}

1. Bell GI, Kayano T, Buse JB, Burant CF, Takeda J, Lin D, et al. Molecular biology of mammalian glucose transporters. Diabetes Care. 1990;13:198-208.

2. Marshall BA, Ren JM, Johnson DW, Gibbs EM, Lillquist JS, Soeller WC, et al. Germline manipulation of glucose homeostasis via alteration of glucose transporter levels in skeletal muscle. J Biol Chem. 1993;268:18442-5.

3. Ren JM, Marshall BA, Gulve EA, Gao J, Johnson DW, Holloszy JO, et al. Evidence from transgenic mice that glucose transport is rate-limiting for glycogen deposition and glycolysis in skeletal muscle. J Biol Chem. 1993;268:16113-5.

4. Hirshman MF, Goodyear LJ, Wardzala LJ, Horton ED, Horton ES. Identification of an intracellular pool of glucose transporters from basal and insulin-stimulated rat skeletal muscle. J Biol Chem. 1990;265:987-91.

5. Marette A, Burdett E, Douen A, Vranic M, Klip A. Insulin induces the translocation of GLUT4 from a unique intracellular organelle to transverse tubules in rat skeletal muscle. Diabetes. 1992;41:1562-9.

6. Goodyear LJ, Hirshman MF, Smith RJ, Horton ES. Glucose transporter number, activity, and isoform content in plasma membranes of red and white skeletal muscle. Am J Physiol. 1991;261 Pt 1:E556-61.

7. Henriksen EJ, Bourey RE, Rodnick KJ, Koranyi L, Permutt MA, Holloszy JO. Glucose transporter protein content and glucose transport capacity in rat skeletal muscles. Am J Physiol. 1990;259 Pt 1:E593-8.

8. Marette A, Richardson JM, Ramlal T, Balon TW, Vranic M, Pessin JE, et al. Abundance, localization, and insulin-induced translocation of glucose transporters in red and white muscle. Am J Physiol. 1992;263 Pt 1:C443-52.

9. Izumiya Y, Hopkins T, Morris C, Sato K, Zeng L, Viereck J, et al. Fast/Glycolytic muscle fiber growth reduces fat mass and improves metabolic parameters in obese mice. Cell Metab. 2008;7:159-72.

10. Kern M, Wells JA, Stephens JM, Elton CW, Friedman JE, Tapscott $E B$, et al. Insulin responsiveness in skeletal muscle is determined by glucose transporter (GLUT4) protein level. Biochem J. 1990;270:397-400.

11. Lillioja S, Young AA, Culter CL, Ivy JL, Abbott WG, Zawadzki JK, et al. Skeletal muscle capillary density and fiber type are possible determinants of in vivo insulin resistance in man. $\mathrm{J}$ Clin Invest. 1987;80:415-24.

12. Zierath JR, He L, Guma A, Odegoard Wahlstrom E, Klip A, Wallberg-Henriksson $\mathrm{H}$. Insulin action on glucose transport and plasma membrane GLUT4 content in skeletal muscle from patients with NIDDM. Diabetologia. 1996;39:1180-9.

13. Andersen PH, Lund S, Schmitz O, Junker S, Kahn BB, Pedersen 0 . Increased insulin-stimulated glucose uptake in athletes: the importance of GLUT4 mRNA, GLUT4 protein and fibre 
type composition of skeletal muscle. Acta Physiol Scand 1993; 149:393-404.

14. Houmard JA, Egan PC, Neufer PD, Friedman JE, Wheeler WS, Israel RG, et al. Elevated skeletal muscle glucose transporter levels in exercise-trained middle-aged men. Am J Physiol. 1991;261 Pt 1:E437-43.

15. Houmard JA, Shinebarger MH, Dolan PL, Leggett-Frazier $\mathrm{N}$, Bruner RK, McCammon MR, et al. Exercise training increases GLUT-4 protein concentration in previously sedentary middle-aged men. Am J Physiol. 1993;264 Pt 1: E896-901.

16. Hardin DS, Azzarelli B, Edwards J, Wigglesworth J, Maianu L, Brechtel G, et al. Mechanisms of enhanced insulin sensitivity in endurance-trained athletes: effects on blood flow and differential expression of GLUT 4 in skeletal muscles. J Clin Endocrinol Metab. 1995;80:2437-46.

17. Jessen N, Goodyear LJ. Contraction signaling to glucose transport in skeletal muscle. J Appl Physiol. 2005;99: $330-7$.

18. Pette D. Training effects on the contractile apparatus. Acta Physiol Scand. 1998;162:367-76.

19. Dela F, Mikines KJ, von Linstow M, Secher NH, Galbo H. Effect of training on insulin-mediated glucose uptake in human muscle. Am J Physiol. 2006;263:E1134-43.

20. Richter EA, Hargreaves M. Exercise, GLUT4, and skeletal muscle glucose uptake. Physiol Rev. 2013;93:993-1017.

21. Gallagher PM, Touchberry CD, Teson K, McCabe E, Tehel M, Wacker MJ. Effects of an acute bout of resistance exercise on fiber-type specific GLUT4 and IGF-1R expression. Appl Physiol Nutr Metab. 2013;38:581-6.

22. Newsom SA, Schenk S. Interaction between lipid availability, endurance exercise and insulin sensitivity. Med Sport Sci. 2014;60:62-70.

23. Higashida K, Tabata I, Higuchi M, Terada S. Regulation of skeletal muscle GLUT-4 expression by exercise and nutritional stimuli. J Phys Fitness Sports Med. 2013;2:355-60.

24. Hussey S, McGee S, Garnham A, McConell G, Hargreaves M. Exercise increases skeletal muscle GLUT4 gene expression in patients with type 2 diabetes. Diabetes Obes Metab. 2012;14:768-71.

25. Mortensen B, Friedrichsen M, Andersen NR, Alibegovic AC, Højbjerre L, Sonne MP, et al. Physical inactivity affects skeletal muscle insulin signaling in a birth weight-dependent manner. J Diabetes Complications. 2014;28:71-8.

26. Mohebbi H, Rohani H, Hassan-nia S, Pirooznia N. The effect of obesity and endurance training-induced weight loss on UCP3 mRNA expression in C57BL/6 mice. Ir J Endocrinol Metab. 2013;15:311-21.

27. Pfaffl MW. A new mathematical model for relative quantification in real-time RT-PCR. Nucleic Acids Res. 2001;29:e45.

28. Ploug T, Van Deurs B, Ai H, Cushman SW, Ralston E. Analysis of GLUT4 distribution in whole skeletal muscle fibers: identification of distinct storage compartments that are recruited by insulin and muscle contractions. J Cell Biol. 1998;142: 1429-46

29. Malide D, Dwyer NK, Blanchette-Mackie EJ, Cushman SW. Immunocytochemical evidence that GLUT4 resides in a specialized translocation post-endosomal VAMP2-positive compartment in rat adipose cells in the absence of insulin. J Histochem Cytochem. 1997;45:1083-96.

30. Hughes VA, Fiatarone MA, Fielding RA, Kahn BB, Ferrara CM, Shepherd P, et al. Exercise increases muscle GLUT-4 levels and insulin action in subjects with impaired glucose tolerance. Am J Physiol. 1993;264 Pt 1:E855-62.

31. Friedman JE, Sherman WM, Reed MJ, Elton CW, Dohm GL. Exercise training increases glucose transporter protein GLUT4 in skeletal muscle of obese Zucker $(\mathrm{fa} / \mathrm{fa}$ ) rats. FEBS Lett. 1990;268:13-6.
32. Ishihara H, Asano T, Katagiri H, Lin JL, Tsukuda K, Inukai K, et al. Expression of GLUT-4 glucose transporter in unweighted soleus muscle of normal and STZ-induced diabetic rats. Am J Physiol. 1993;264 Pt 1:E301-7.

33. Holman GD, Cushman SW. Subcellular localization and trafficking of the GLUT4 glucose transporter isoform in insulinresponsive cells. Bioessays. 1994;16:753-9.

34. Daugaard JR, Richter EA. Relationship between muscle fibre composition, glucose transporter protein 4 and exercise training: possible consequences in non-insulin-dependent diabetes mellitus. Acta Physiol Scand. 2001;171:267-76.

35. Brozinick J, Etgen G, Yaspelkis B, Kang H, Ivy J. Effects of exercise training on muscle GLUT-4 protein content and translocation in obese Zucker rats. Am J Physiol Metab. 1993;265:E419-27.

36. O'gorman D, Karlsson H, McQuaid S, Yousif O, Rahman Y, Gasparro D, et al. Exercise training increases insulin-stimulated glucose disposal and GLUT4 (SLC2A4) protein content in patients with type 2 diabetes. Diabetologia. 2006;49:2983-92.

37. Dohm GL. Invited review: regulation of skeletal muscle GLUT-4 expression by exercise. J Appl Physiol. 2002;93:782-7.

38. Chiu L-L, Chou S-W, Cho Y-M, Ho H-Y, Ivy JL, Hunt D, et al. Effect of prolonged intermittent hypoxia and exercise training on glucose tolerance and muscle GLUT4 protein expression in rats. J Biomed Sci. 2004;11:838-46.

39. Kraniou GN, Cameron-Smith D, Hargreaves M. Effect of shortterm training on GLUT-4 mRNA and protein expression in human skeletal muscle. Exp Physiol. 2004;89:559-63.

40. Castorena CM, Arias EB, Sharma N, Bogan JS, Cartee GD. Fiber type effects on contraction-stimulated glucose uptake and GLUT4 abundance in single fibers from rat skeletal muscle. Am J Physiol Metab. 2015;308:E223-30.

41. Garrett WE, Kirkendall DT. Exercise and sport science. Philadelphia: Lippincott Williams \& Wilkins; 2000. p. 171-3.

42. Gaster M, Poulsen P, Handberg A, Schrøder H, Beck-Nielsen H. Direct evidence of fiber type-dependent GLUT-4 expression in human skeletal muscle. Am J Physiol Metab. 2000;278: E910-6.

43. Raychaudhuri N, Thamotharan S, Srinivasan M, Mahmood S, Patel MS, Devaskar SU. Postnatal exposure to a highcarbohydrate diet interferes epigenetically with thyroid hormone receptor induction of the adult male rat skeletal muscle glucose transporter isoform 4 expression. J Nutr Biochem. 2014;25:1066-76.

44. Weems JC, Griesel BA, Olson AL. Class II histone deacetylases downregulate GLUT4 transcription in response to increased CAMP signaling in cultured adipocytes and fasting mice. Diabetes. 2012;61:1404-14.

45. Kawanaka K, Higuchi M, Ohmori H, Shimegi S, Ezaki O, Katsuta S. Muscle contractile activity modulates GLUT4 protein content in the absence of insulin. Horm Metab Res. 1996;28: 75-80.

46. Holten MK, Zacho M, Gaster M, Juel C, Wojtaszewski JF, Dela F. Strength training increases insulin-mediated glucose uptake, GLUT4 content, and insulin signaling in skeletal muscle in patients with type 2 diabetes. Diabetes. 2004;53: 294-305.

47. Friedman JE, Ishizuka T, Liu S, Farrell CJ, Bedol D, Koletsky RJ, et al. Reduced insulin receptor signaling in the obese spontaneously hypertensive Koletsky rat. Am J Physiol Metab. 1997;273:E1014-23.

48. Shao J, Yamashita H, Qiao L, Friedman J. Decreased Akt kinase activity and insulin resistance in C57BL/KsJ-Leprdb/db mice. J Endocrinol. 2000;167:107-15.

49. Furuta M, Yano Y, Gabazza EC, Araki-Sasaki R, Tanaka T, Katsuki A, et al. Troglitazone improves GLUT4 expression in adipose tissue in an animal model of obese type 2 diabetes mellitus. Diabetes Res Clin Pract. 2002;56:159-71. 
50. Tozzo E, Gnudi L, Kahn BB. Amelioration of insulin resistance in streptozotocin diabetic mice by transgenic overexpression of GLUT4 driven by an adipose-specific promoter 1. Endocrinology. 1997; 138:1604-11.

51. McGee SL, van Denderen BJ, Howlett KF, Mollica J, Schertzer $\mathrm{JD}$, Kemp BE, et al. AMP-activated protein kinase regulates
GLUT4 transcription by phosphorylating histone deacetylase 5. Diabetes. 2008;57:860-7.

52. Raychaudhuri N, Raychaudhuri S, Thamotharan M, Devaskar $\mathrm{SU}$. Histone code modifications repress glucose transporter 4 expression in the intrauterine growth-restricted offspring. J Biol Chem. 2008;283:13611-26. 